\title{
TYPES, PURPOSE, AND STRATEGIES OF TEACHER'S QUESTIONS IN INDONESIAN EFL CLASSROOM OF JUNIOR HIGH SCHOOL IN BALI
}

\author{
Paramartha, A. A. G. Y. \\ English Language Education, Faculty of Language and Art \\ Ganesha University of Education \\ Singaraja, Indonesia \\ Email: yudha.paramartha@undiksha.ac.id \\ Ramawati, N. M. S. \\ English Language Education, Faculty of Language and Art \\ Ganesha University of Education \\ Singaraja, Indonesia \\ Email: seriramawati@gmail.com \\ Suputra P. E. D. \\ English Language Education, Faculty of Language and Art \\ Ganesha University of Education \\ Singaraja, Indonesia \\ Email: eka.dambayana@undiksha.ac.id.
}

\begin{abstract}
This study was a case study which aimed to analyze the types of questions used by an English teacher, the purposes of questions asked by the teacher, and the strategy used to cope with non-responded questions. The subject of this study was an English teacher who taught seventh grade students at SMPN 1 Singaraja which is located in Singaraja, Buleleng regency, Bali, Indonesia. The data were collected through observation, interview, and video recording. The result of the analysis showed that from 241 questions, the teacher more frequently asked convergent, closed, and display questions rather than divergent, open, and referential questions. Procedural questions were also found. The teacher's questions served several purposes such as to check students' knowledge and understanding, to attract students' activeness, to develop students' interest and curiosity, and to stimulate students in stating information. It was also found that the teacher used seven strategies to cope with non-responded questions. This study suggested the teacher to balance the number of convergent, closed, and display with divergent, open, and referential questions to be used during teaching and learning process. In addition, the teacher should know more about the strategies for non-responded questions and the proper way to use those strategies to make the teaching and learning process runs smoothly.
\end{abstract}

Keywords: EFL, questions, teacher's questions

\section{INTRODUCTION}

Conducting teaching and learning process is a complex task. "Teaching and learning process is a complex and multi-faced issue"(Hamiloglu \& Temiz, 2012). In line with that statement, Helmiati (2013:18) also states that teaching skill is a complex professional competence which consists of technology, arts, and value. She also adds that when teaching in the classroom, teacher needs to apply several skills which are based on moral value and utilizing technology. English teachers need to master eight basic teaching skills (Helmiati, 2013:19). Meanwhile, Mukminan (2013:209) states that there are ten basic teaching skills that need to be mastered by English teachers. From all of the skills, questioning is the activity that is mostly done by teachers around thirty-five to fifty percents of teachers' instructional time(Cotton, 1988). According to Jansem(as cited in Meng, Zhao, and Chattouphonexay, 2012), teacher asks questions before, during, and after instruction which means teacher's questions appear in the three phases of teaching namely pre-teaching, whilst-teaching, and post teaching.

Question is defined as any interrogative sentence which is uttered by the speaker in order to get information from the hearer(Erlinda \& Dewi, 2014). In classroom setting, question can be defined as 
instructional cue or stimuli that helps teacher to convey the content of lesson that need to be learnt and direction on what should the students do and how the students do it (Cotton, 1988).

There are several types of questions which are proposed by several experts. In terms of the purposes, there are procedural, divergent, and convergent questions (Richards \& Lockhart as cited in Hamiloğlu\&Temiz, 2012). Procedural questions are questions which has something to do with the classroom routine. Divergent questions are questions that encourage students to give their opinion or judgment instead of recall previous information. And convergent questions are questions that require students to recall previous information. According to the kind of responses, there are open and closed questions (Tsui as cited in Yang, 2010). Closed questions are questions which only accept one correct answer meanwhile open questions are questions that accept more than one correct answer. In terms of the nature of interaction, there are display and referential questions (Kao \& Weng, 2012). Display question is defined as question in which the answer is already known by the teacher. On the other hand, referential question is question where the answer is not known by the teacher.

The types of the questions used by the teacher are important since it determines the range opportunity of the students to use the target language which is through answering the questions(Erlinda \& Dewi, 2014). Moreover, Erlinda and Dewi (2014) also add the types of questions used by teacher determine the length of the students' responses. Yang (2010) found that asking open and referential questions have positive correlation which means those types of questions can elicit long responses. Meanwhile, he also found that closed and display questions have negative correlation which means those types of questions elicit short responses.

Questions which uttered by teachers during teaching learning process serve several purposes such as to develop students interest and curiosity, to get students' attention, to evaluate students' preparation and to check on homework, to develop students' critical thinking, to review or recall the previous lesson or subtopic, to assess students' achievement, to encourage students to get the knowledge on their own, to give students time to understand the material, to stimulate students in stating information, to check students' knowledge, to diagnose students' difficulty in learning process, and to motivate and attract students activeness (Cotton ,2001 \&Padmadewi, et. al., 2017:102). The students sometimes do not answer teacher's questions because they lack of knowledge towards the topic discussion or lack of vocabularies. The strategies that the teacher can use to cope with nonresponded questions are simplifying the questions, repeating the questions, employing additional questions, giving longer wait time, helping with body language, explaining, giving example, and answering(Meng, Zhao, \& Chattouphonexay, 2012).

The importance of asking questions is also magnified by several studies such as a study conducted by Ndun (2015) about the types of the teacher's questions, the functions of the questions, and the lengths of the students responses. In 2016, Yuliawati, Mahmud and Muliati conducted study about the relation between teacher's questioning and students' critical thinking in EFL classroom at SMAN 1 Tolotoli. Another study by Sujariati, Rahman, and Mahmud (2016) investigated about English teacher's questioning strategies in EFL classroom at SMAN 1 Bontomarannu. In addition, AlZahrani and Al-Bargi (2017) also conducted a study about the effect of questions to create interaction and the characteristics of questions which can increase classroom interaction.

Based on the result of preliminary observation, it was found that the English teacher of seventh grade students at SMP Negeri 1 Singaraja asked questions to students during teaching and learning process at the beginning, in the middle, and at the end of the lesson. Considering the importance of questioning in the learning process, this study was interested to investigate the teacher's questions. Since there was no study which investigated the teacher's questions in SMP Negeri 1 Singaraja, then this study was conducted to investigate about the types of questions which were used by an English teacher in EFL classroom at SMPN 1 Singaraja, the purposes of the teacher in asking the questions, and the strategies which were used to cope with non-responded questions. Hopefully this study can give benefits for other teachers and teachers' candidates about questioning in teaching and learning process. The result of this study can enrich knowledge and information for Micro Teaching and Classroom Management especially about types of questions that can be used during teaching and learning process and how to cope with non-responded questions in order to make the teaching and learning process run well. 


\section{METHODS}

This study was a case study. A case study is defined as a series of scientific activity which is done in detail, deep, and intensively about a program, event, and activity whether individual, group, or organization to get deep information and knowledge regarding that event(Rahardjo, 2017). The setting of the study was SMP Negeri 1 Singaraja which is located at Gajah Mada street No. 109, Buleleng Sub district Buleleng Regency, Bali, Indonesia. The subject of this study was an English teacher who taught seventh grade students at SMPN 1 Singaraja in academic year of 2017/2018. There were several techniques which were used to collect the data namely observation, interview, and video recording. The instruments used in this study were check list, interview guide, and video recorder. The data were analyzed using Interactively Data Analysis Model by Miles and Huberman (1984). There are four steps in this analysis model namely data collection, data reduction, data presentation, conclusion drawing and data verification.

In data collection, the researcher conducted observation, interview, and recording. The second step was data reduction where the data were transcribed and then if there were data which were not related with the objective of the study, then those data were deleted. The next step was data presentation or also known as data display. In this step, the data were classified based on its type of questions, the purposes as well as the strategies to cope with non-responded questions in the form of tables. The last step in Interactively Data Analysis Model is making conclusion and verified the result of the study. After the data of the types of questions, purposes of the questions, as well as the strategies to cope with the non-responded questions were written in tables, then the researcher made conclusion and verified the result of the study.

\section{RESULT AND DISCUSSION Types of Questions}

In the observation, the teacher asked 284 questions during teaching and learning process. However, there were several questions which were eliminated since those questions did not meet the criteria for the study. Specifically, the questions used in this study were the questions which acted as stimulations, cues, or instructions which help the teacher convey the content of the lesson. After selecting the data, it was found from 284 questions which were uttered by the teacher, only 241 questions were used and analyzed in this study. The detail number of questions can be seen in Table 1.

Table 1 Total Number of Questions Uttered by the Teacher

\begin{tabular}{llcc}
\hline No & \multicolumn{1}{c}{ Days } & $\begin{array}{c}\text { Number of Questions } \\
\text { Occur }\end{array}$ & $\begin{array}{c}\text { Number of Questions } \\
\text { Analyzed }\end{array}$ \\
\hline 1 & Monday, April 30th 2018 & 64 & 52 \\
2 & Monday, May 7th 2018 & 71 & 63 \\
3 & Tuesday, May 8th 2018 & 69 & 54 \\
4 & Wednesday, May 9th 2018 & 80 & 72 \\
Total Number of Questions & 284 & 241 \\
\hline
\end{tabular}

In classifying the data of the types of questions used by the English teacher at SMP Negeri 1 Singaraja, the researcher used theory from Richards and Lockhart (as cited in Hamiloğlu\&Temiz, 2012), Tsui (as cited in Yang, 2010), and Kao and Weng (2012). The detail number of questions can be seen in Table 2 .

Table 2. Types of Questions Asked by the Teacher 


\begin{tabular}{|c|c|c|c|}
\hline \multicolumn{2}{|c|}{ Question Type } & Number & Percentage \\
\hline \multirow{3}{*}{$\begin{array}{l}\text { Richards and } \\
\text { Lockhart }\end{array}$} & Procedural & 15 & $6.20 \%$ \\
\hline & Convergent & 191 & $79.30 \%$ \\
\hline & Divergent & 35 & $14.50 \%$ \\
\hline \multicolumn{2}{|c|}{ Total } & 241 & $100 \%$ \\
\hline \multirow{2}{*}{ Tsui } & Closed & 179 & $79.20 \%$ \\
\hline & Open & 47 & $20.80 \%$ \\
\hline \multirow{4}{*}{ Kao and Weng } & & 226 & $100 \%$ \\
\hline & Display & 148 & $65.50 \%$ \\
\hline & Referential & 78 & $34.50 \%$ \\
\hline & & 226 & $100 \%$ \\
\hline
\end{tabular}

Table 2 describes the categorization of questions types according to Richards and Lockhart revealed that the teacher mostly asked convergent questions. The total number of convergent questions which occurred was 191 with the percentage was $79.30 \%$ which is more than a half of the total of questions. The examples of this type of questions were like "Can you mention creatures in the forest?", "Can you find deer in the forest?", and "Do you have a pet?.Meanwhile, the second position was placed by divergent questions with the total number was 35 and the percentage was $14.50 \%$. The example was like "Why do you agree?". And the last one is procedural questions such as "Are you done?" and "Is that clear?". This type of questions was rarely asked by the teacher which occured only 15 times from the total of the questions in four meetings and the percentage was $6.20 \%$.

The data of the questions uttered by the teacher were also analyzed based on the theory proposed by Tsui (as cited in Yang, 2010). According to Tsui (as cited in Yang, 2010), there are two types of questions namely open and closed questions. Before analyzing the data to classify whether it is close or open questions, the total number of questions was decreased. Only the questions which related with the content of the lesson were used or in other words the procedural questions were not included.

Based on Table 2, from the total number of questions in which the number of procedural question has been deleted, it was found that the total number of closed questions was 179 with the percentage was $79.20 \%$. Meanwhile, $20.80 \%$ of the questions were open questions with the total number in four meetings was 47. The examples of closed questions namely "Do you know spot?", "Do you have a pet?" and "Can you find it in Bali?". And the examples of open questions were like "Why do you say zebra?", "What do you often do with your dog?", and "Where do you usually bring it?".

Although closed questions are similar with convergent questions and open questions are similar with divergent questions, there is a slight difference between those types of questions. Such questions like "Can you mention animal in the forest?" belongs to open questions because it does not has a specific answer and each students can have different answers. However that question does not belong to divergent question but it is convergent question because it does not need a high level of thinking to answer the questions.

The data of the questions uttered by the teacher were also analyzed using theory proposed by Kao and Weng (2012). The same as analysis using Tsui's theory, before analyzing the data to find out how many questions are display and referential, the researcher reduced the procedural questions first then analyzed the data.Based on Table 2, it was found that display questions appeared more frequently than referential questions. The total number of questions found in four meeting observation was 148 with the percentage was $65.50 \%$. The examples of display question were like "What is garis-garis in English?", "What is kind?", and "Can run or can running?". Meanwhile, the total number of referential questions uttered by the teacher was 78 and the percentage was $34.50 \%$. The example of this types of questions were like "Why do you like your pet?", "What do you often do with your dog?", and "How many dogs do you have?".

\section{Purposes of the Questions}

After analyzing the data, each type of questions served various purposes. There were seven purposes out of twelfth purposes which are stated by Cotton (2001) and Padmadewi, et. al (2017:102). 
Other purposes out of the theories were also found. It was found that procedural questions were used to attract students' activeness for example like "Who else?", "Anybody else?". Here the teacher invited the students to state their answer or opinion. The second purposes of procedural questions was to check students' progress such as "Finished?", "Anybody has finished?", "Who has finished?". After the students were given a task, the teacher usually asked those questions to know the students' progress. The third purposes of procedural questions was to check students' understanding such as after the teacher explained a certain topic, the teacher said "Is that clear?" in order to check whether the students have already understood or not.

The fourth purpose of procedural question was to make the students focus. For example like when the teacher asked one student to give information about a certain topic, the teacher asked "Can you listen to the most handsome guy in the dark?" in order to make students focus towards the lesson. And the last purpose of procedural questions was to encourage students' to speak using English or the target language. When the students answered the teacher's questions using Bahasa Indonesia, the teacher said "Can you speak English please?" to encourage the students to speak using the target language.

Convergent and closed questions are quite similar in which those types of questions require the students' to recall the previous information and also these types of questions do not elicit long answer, usually 'yes' or 'no', or simple words. Since these types of questions are similar, the purposes of these questions were the same. Based on the observation, there were several purposes of convergent and closed questions found in this study. The first one is to develop students' interest and curiosity. The topic of the lesson was describing animal. In the beginning of the lesson, the teacher tried to make the students interested with the lesson by asking such questions like "Can you mention creatures in the forest?", "Do you have a pet?", and "What kinds of pet do you have?".

The second purpose of convergent and closed question is to check students' knowledge. The example of the questions which checking the students' knowledge were like "What is garis-garis in English?", "What is bark?", and "What animal has one big horn?". Here the teacher checked the students' knowledge whether they knew the meaning of English words in Bahasa Indonesia or vice versa. The next purpose of convergent and closed question is to attract students' activeness such as "Do you agree with Dicky Huang?". The teacher wanted the other students' to be active by asking the students whether they agree or not with their friends' answer by asking such question.

The other purpose of convergent and closed question is to make the students' focus. When the teacher asked one student to answer a question, the teacher asked other students' to repeat the student's answer. The examples of the questions are "What did Nikita say?", What did Tio say?", "What does Dicky usually do with his pets?". Since the students asked one student, he also wanted the other students' to focus and pay attention. Others purposes of convergent and closed questions is to check students' understanding, to stimulate students to pursue knowledge on their own, and to review the previous information. For examples like saying "Why does the writer like spot?", Where does it like to run around?", and "What does he do when he tired or sleepy?".

Divergent question is also similar with open questions since these questions elicits long answer in which the students are required to give opinion, reason, or judgment. Taken from the observation, there were several purposes of divergent and open questions found in this study. The first one is to stimulate students in stating information. The examples of these questions which stimulate students to state information were like "Why do you like your pet?", "Why you don't have a pet?". The second purpose of divergent and open questions is to attract students' activeness. For instance the teacher asked "What question next?". Here the teacher wanted the students to be active by giving their opinion towards the lesson. Another purpose found is to develop students' critical thinking. When one student gave an answer, the teacher asked other students' opinion by asking "What do you think?".

One of the purposes of open questions which do not belong to divergent questions was to develop students' interest and curiosity. The questions were "Can you mention creatures in the forest?" and "What kinds of pet do you have?". Those questions were categorized as open questions since the answer can be varied and do not have a specific correct answer. But those questions do not belong to divergent questions because it does not need the students to give reason or opinion and only mentioning the animal. The purpose of those questions is to develop students' interest and curiosity which were asked in the beginning of the lesson. 
Display questions are questions in which the answers are already known by the teacher. This type of question usually used to check students' knowledge and understanding. Based on the observation, there were several purposes of display questions found in this study. Several convergent and closed questions also belonged to display questions such as "What is pet?". That question can be classified into convergent, closed, and display question since the teacher has already known the answer. The purpose of the teacher in asking that question is to check students' knowledge. The other purposes of display questions are to develop students' interest and curiosity and to stimulate students in stating information such as "What else do you know about hippo?". Based on the interview, the teacher agreed and has the same idea that the purposes of display questions were to make sure the students know the meaning of several English words in Bahasa Indonesia, to make the students interested with the lesson being taught, and to encourage the students to give the information that they know.

In contrary with display questions where the answers are known by the teacher, referential questions are questions in which the answers are not known by the teacher. Taken from the observation, the teacher asked several referential questions which served various purposes. The first purpose is to stimulate students in stating information. For instances the teacher asked "How do you feed them?", "How do you know they love you?", and "What do you often do with your pet?". The teacher did not know the answer therefore the teacher asked those questions to get information from the students. The second purpose of referential questions is to develop students' critical thinking. For example like questions "Why not?", "Why do you agree?", and "What do you think?" in which those questions were also categorized as divergent and open questions.

The other purpose of referential questions is to develop students' interest and curiosity. Such questions like "Do you have a pet?", "What kinds of pet do you have?", and "How many dogs do you have?". The teacher asked those questions in the beginning of the lesson to develop students' interest and curiosity towards the lesson. Another purpose of referential question is to stimulate students to pursue knowledge on their own. The teacher asked "Who is correct for A?". When the teacher taught about grammar, the teacher asked students' opinion about which sentence was correct whether A or B. The teacher asked the students' first before he explained the material to stimulate students to get concept by their own.

In brief, the questions which were uttered by the teacher were effective to achieve the purposes of the questions. It can be seen from the students' responds. The questions that the teacher asked were used to help the teacher delivering the material and to make the students speak using English especially in describing animal. The teacher always encouraged the students to speak using English when answering the teacher's questions. The effectiveness of the questions can be seen through the students' answer or reaction towards the questions. If the students can answer the teacher's questions, the teacher said that those questions have already effective enough to achieve its purpose.

\section{Strategies Used to Cope with Non-Responded Questions}

When conducting observation in the classroom during teaching and learning process, it was found that several questions were not responded by the students. The students did not respond the questions because of they have lack of vocabulary to answers the questions and the questions were something new. The detail number of questions which were not responded by students can be seen in Table 3.

Table 3. The Number of Questions which were not Responded by Students

\begin{tabular}{lllllll}
\hline Observation & \multicolumn{4}{c}{ The frequency of occurrence } & \multirow{2}{*}{ Total } & Percentage \\
\cline { 2 - 5 } & Day 1 & Day 2 & Day 3 & Day 4 & & \\
Number of questions & 52 & 63 & 54 & 72 & 241 & $100 \%$ \\
Responded & 45 & 57 & 50 & 65 & 217 & $90 \%$ \\
Not-Responded & 7 & 6 & 4 & 7 & 24 & $10 \%$ \\
\hline
\end{tabular}

From 241 questions which were uttered by the teacher, 217 questions were responded by the students with the percentage was $90 \%$. Meanwhile, 24 questions were not responded by the students. 
The percentage of non-responded questions was $10 \%$. Based on the observation, the teacher used five strategies out of eight which were proposed by Meng, et. al (2012) namely repeating the question, employing additional question, helping with body language, longer wait time and answering. The researcher also found other strategies used by the teacher to cope with non-responded questions namely helping the students by giving clue and peer help.

In short, the strategies which were used by the teacher to cope with the non-responded questions were effective. It is because when the teacher modified the non-responded question and used those strategies, the students could understand what the teacher's questions means. The teacher also stated that by looking at the reaction of the students such as the students finally could answer the questions, the teacher knew that the strategies were effective.

\section{Discussion}

This study aimed to find out the types of questions used by an English teacher at SMP Negeri 1 Singaraja, the purposes of asking such questions, and the strategies to cope with non-responded questions. Based on the result of the observation, the teacher uttered various types of questions in teaching and learning process. The teacher used all of the types of questions namely procedural questions, convergent questions, divergent questions, closed questions, display questions, open questions, and referential questions. Based on the result of the study, the teacher frequently asked convergent, closed, and display questions instead of divergent, open, and referential questions. Several studies which were conducted by Erlinda and Dewi (2014), Yang (2010), Meng, Zhao, and Chattouphonexay (2012), and Ndun (2015) also found that convergent, closed, and display questions were appeared most frequently during teaching and learning process.

The result of the finding reveals that several types of questions have similarities. Convergent, closed, and display questions were quite similar. Those types of questions did not promote high order of thinking where the students were only required to recall the knowledge or information which has been taught. The answer of the questions were usually simple and short such as 'yes' or 'no' and simple phrases. Meanwhile, divergent, open, and referential questions were also quite similar. Those types of questions were high cognitive questions in which the students were asked to give their opinion and also information based on their experience. These statements are consistent with Erlinda and Dewi (2014) who state that closed and display questions belong to convergent questions, meanwhile open and referential questions belong to divergent questions.

However, those types of questions also have differences. It is not always one question if it is categorized as convergent question, it will also belong to closed and display questions. A convergent question can be also categorized as open and referential questions because that question is not really need a high order of thinking, but it accepts various correct answers and the teacher does not know what the students' answer is. Therefore, not all of convergent questions are closed and display questions, and divergent questions are open and referential questions since each types of questions has its definition.

The choice of the types of questions asked by the teacher was because of the content of the lesson and also the students' language proficiency. According to Ndun (2015), the type of question uttered by teacher is related with the content and the pedagogical purposes of the lesson. In addition, Meng, Zhao, and Chattouphonexay (2012) proposed three reasons which are responsible why teacher prefers asks certain types of questions namely 1) teacher assumptions in which the teacher thinks that the students' could not answer such divergent, open, or referential questions although actually several top students could answer it, 2) students' language proficiency in which the students have low ability in English, 3) the content of the lesson.

The topic of the lesson was describing animal which is factual content. There was limited discussion which need students to give opinion or to elaborate ideas and it might be one of the cause why convergent, closed, and display questions occurred most. Meng, Zhao, and Chattouphonexay (2012) also state that when the content of the lesson is about fact, mostly the types of questions asked by the teacher will be convergent, closed, or display questions which requires the students to state factual information instead of giving opinion or judgment.

In both classes, the teacher also taught grammar which was about the structure of simple present tense. When the teacher taught grammar, there is no authentic communication between the teacher and the students. Littlewood (as cited in Yang, 2010) suggests that in teaching grammar, 
before having the students to have a communicative language practice, the teacher often wants to engage the students to learn the language first in order to make the student focus on the structure itself. In addition, he also states that it can be achieved through questioning and answering. The major purpose of the teacher's questions is to check the students' understanding and knowledge in order to make them able to speak English correctly. Therefore, convergent, closed, and display questions occurred most.

However, in one class, although convergent and closed questions outnumbered divergent and open questions, it was found that referential questions were uttered more than display questions. The reason why it can happen is because of the ability of the students on that class is better than the other class. Therefore, in that class, the teacher did not spend a lot of time to teach grammar which caused referential questions occurred more than display questions. On the other hand, in other class where the ability of the students was lower than the previous class, the teacher mostly asked display questions. It shows that the teacher's type of questions is also influenced by the students' ability in English.

The questions asked by the teacher served several purposes. The purposes of the questions asked by the teacher were also consistent with the findings from several studies which were conducted by Erlinda and Dewi (2014) and Ndun (2015). Most of the questions which were uttered by the teacher were used to check students' knowledge and understanding. The teacher wanted to make sure that the students do understand some vocabularies items both in English and Bahasa Indonesia. The questions were also used to make the students interested with the lesson. Those questions could guide the students to the content of the lesson. If the students are interested with the lesson, it will be easier for them to understand the material.

The teacher also has the same view about the purposes of the questions, however there were several questions in which the teacher has different opinion about its purpose. The teacher said the purpose of several convergent, closed, open, and referential questions was to give model to students or modeling and the purpose of one question which belongs to convergent, open, and display question was to relate students' prior knowledge with the new information. The teacher asked the questions in the beginning of the lesson. Helmiati (2013:44) states that teacher open the class by applying set induction skill or open and closing skill where the teacher should develop students' interest and curiosity and it can be done through questioning. Therefore, the purpose of asking questions was to develop students' interest and curiosity towards the topic of the lesson.

Looking at the empirical review, the purposes of the questions were consistent with the finding of several studies. Farahian and Rezaee (2012) state that the purposes of convergent, closed, and display questions are to make sure the students understand the material that has been taught and to check students' comprehension of grammatical points or vocabulary item. Meanwhile, the purpose of open and referential questions is used as warming up which are asked in the beginning of the lesson to make the students interested with the lesson. Yang (2010) also found the purpose of closed and display question is to check students' knowledge of vocabulary item. He also found that referential questions are usually asked in the beginning of the lesson as a warming up. And then, Ndun (2015) also found that the purpose of divergent, open, and referential questions is to stimulate or to elicit information from the students which also consistent with the finding in this study.

The responses of the students towards convergent, closed, and display questions were short, usually 'yes' or 'no', a single word, or simple phrase. The teacher usually asked these types of questions to whole class. Yang (2010) and Shomoossi (2004) also found similar finding. Display questions produced short answers compare with referential questions. Tuan and Nhu (2010) also state that possible answers of these types of questions are limited. In addition, they state that to make the students produce complex or long sentences, the questions should not limit the range choices. These questions were answered in chorus which did not encourage students to give their opinion. Al-Zahrani and Al-Bargi (2017) also argue that display questions could prevent students to express their thought and only recalling previous knowledge or information. Therefore, these types of questions are not effective to stimulate students in giving opinion and to develop students' critical thinking.

The response of the students when they were asked divergent, open, and referential questions was quite longer than their response toward convergent, closed, and referential questions. Several referential questions elicit non-verbal reaction which is also found by Yang (2010) where the response of the students was by raising hands. Richards and Schmidt (as cited in Meng, Zhao, and Chattouphonexay , 2012) suggested the teacher to use referential questions more often than asking 
display questions to make the class more communicative. However, the finding reveals that when the teacher asked open and referential questions, the students needed more time to think about it. There was a student who has low ability in English, that student needed more time to think about the answer of referential questions. This finding is also consistent with the study which was conducted by Erlinda and Dewi (2014). They found that the students took longer time to answer referential and open questions compared with closed and display questions. It might be also the cause why the teacher asked closed and display more often instead of open and referential questions.

Although divergent, open, and referential questions elicit longer answers compare with convergent, closed, and display questions, it does not mean that convergent, closed, and display questions are not important to be asked during teaching and learning process. Shomoossi (2004) states that it would be dangerous to conclude that divergent, open, and referential questions are more useful meanwhile convergent, closed, and display questions are useless. He also adds that each context needs appropriate strategy. In this study, the students were seventh grade students and the topic of the lesson did not require the students to think in high level of thinking such as interpreting ideas or elaborating some ideas. The teacher's question was used to encourage students communicate using the target language. As suggested by Shomoossi (2004), students who are beginners, display questions are useful for them to encourage the students and to develop students' interest. In addition, Matra (2014) state that asking lower cognitive questions are effective to help students committing factual information that they know. Thus, convergent, closed, and display questions are quite useful and effective for beginners.

Several questions were not responded by the students. The students' language proficiency and the students' knowledge towards the lesson were the causes of several questions were not responded. There were seven strategies which were used by the teacher to cope with those non-responded questions. Dominantly, the teacher employed additional questions and repeated the questions to cope with non-responded questions. It seems like the teacher knew that the students actually understood the meaning of the questions, but the students looked reluctant to answer the questions. They might be afraid if their answer was wrong or they did not know how to say it in English.

The finding was also consistent with the result of the interview with the teacher in which the teacher also said that he usually do several strategies when coping with non responded questions such as answering, explaining, or asked other students' to answer the questions. However, the teacher did not state all the strategies which he used to cope with non responded questions during teaching and learning process. The teacher seemed like used the strategy naturally or in other words he unconsciously used the strategy. Although the teacher did not realize he actually has used several strategies in coping with non-responded questions, those strategies were effective to make the students were able to answer the questions.

From the result of the study, apart from which types of questions appeared most since all types of questions are useful, it can be generalized that the teacher's questions play an important role in teaching and learning process especially in EFL classroom. Asking question is an effective way to give students chance to speak using the target language through answering the teacher's questions. It is also supported by the study conducted by Matra (2014) in which the students can speak up and contribute in classroom discussion through answering teacher's questions. Teacher's questions also can create interaction between teacher and students. Teacher's positive feedback can encourage students to be braver to speak English. When the students give a positive feedback towards the students' response, the students will not feel afraid if they might do some mistakes. And also, as a teacher, it is important to learn how to cope with non-responded questions. There might be reasons why students' cannot answer the questions. Thus, appropriate strategy is needed instead of blaming the students.

The finding found in this study was limited by the subject and the object of the study. The subject of this study was an English teacher. Further research is suggested to use more than one teacher is needed in order to get deeper information regarding the types of questions asked by EFL teachers during teaching and learning process, the purposes, and the strategy used by teachers in coping with non-responded questions. In addition, this study only focused on the teacher's questions. Thus, conducting study about the students' responses is also encouraged to get a better understanding towards the role of questions in teaching English as a foreign language. 


\section{CONCLUSION}

From the result of the study, it can be concluded that the English teacher who taught seventh grade students at SMP Negeri 1 Singaraja asked various types of questions. The teacher used all of the types of questions namely convergent, closed, display, divergent, open, and referential questions. The teacher mostly asked convergent, closed, and display questions. Several procedural questions were also found in this study. Although this type of questions do not related with the content of the lesson, this types of question is still important to check students' understanding, to engage the students to content of the lesson, and to encourage students to speak using target language.

The questions uttered by teacher served several purposes. Dominantly, the purpose of the teacher's questions is to check students' knowledge and understanding, as well as to develop students' interest and curiosity. It means the teacher uttered questions to know whether the students have already understood or just to recall the previous information.

In coping with non-responded questions, the teacher used five out of seven strategies namely employing additional question, repeating, longer wait time, helping with body language, and answering. Two other strategies were also found namely giving clue and peer help. Dominantly, the teacher employed additional questions and repeated the questions to make the students were able to answer the questions

Based on result of the study, some suggestions were found. The first one is for English teachers in which the result of this study is expected to give guidance for the teacher to ask various types of questions especially divergent, open, and referential questions. Since those types of questions can promote the students to think critically and elicit more authentic communication which is not only recalling information. The second one is for other researcher. Since there was a lot of limitation in this study, it is suggested for the other researcher who is interested to conduct similar study to find out the students' responses towards each type of questions to make sure the effectives of the types of questions.

\section{REFERENCES}

Al-Zahrani, M. Y., \& Al-Bargi, A. (2017). The Impact of Teacher Questioning on Creating Interaction in EFL: A Discourse Analysis. English Language Teaching, 10(6), 135. https://doi.org/10.5539/elt.v10n6p135

Cotton, K. (1988). Classroom Questiong. School Improvement Research Series Research, (1989).

Erlinda, R., \& Dewi, S. R. (2014). Teacher'S Questions in Efl Classroom. Ta'dib, 17 NO.2, 177188.Retrieved http://ecampus.iainbatusangkar.ac.id/ojs/index.php/takdib/article/view/271/269

from

Farahian, M., \& Rezaee, M. (2012). A Case Study of an EFL Teacher's Type of Questions: An Investigation into Classroom Interaction. Procedia - Social and Behavioral Sciences, 47, 161167. https://doi.org/10.1016/j.sbspro.2012.06.631

Hamiloglu, K., \& Temiz, G. (2012). The impact of teacher questions on student learning in efl. Journal of Educational and Instructional Studies in the World of Educational and Instructional Studies in the World, 2(2), 1-8.Retrieved from http://www.wjeis.org/FileUpload/ds217232/File/01.hamiloglu.pdf

Helmiati. (2013). Micro Teaching Melatih Keterampilan Dasar Mengajar. https://doi.org/Katalog Dalam Terbitan

Kao, S.-M., \& Weng, W.-C. (2012). "Do You Understand?": An Analysis of Native and Non-native EFL Teachers'Questioning Patterns at a Taiwanese Cram School. Asian EFL Journal, 14(4), 3968.Retrieved from http://asian-efl-journal.com/wpcontent/uploads/mgm/downloads/33712500.pdf

Matra, S. D. (2014). Teacher Questioning in Classroom Interaction. A Journal of Culture, English LanguageTeaching \& Literature, 14(1), 82-111.Retrieved from http://journal.unika.ac.id/index.php/celt/article/download/58/50

Meng, J., Zhao, T., \& Chattouphonexay, A. (2012). Teacher Questions in a Content-based Classroom for EFL Young Learners. Theory and Practice in Language Studies, 2(12), 2603-2610. https://doi.org/10.4304/tpls.2.12.2603-2610 
Miles, M. B., \& Huberman, A. M. (1984). Qualitative Data Analysis : Handout. A Sourcebook of New Methods. California; SAGE Publications Inc., (1-8).

Mukminan. (2013). Keterampilan Dasar Mengajar. Pusat Pengembangan Kurikulum Instruktional dan Sumber Belajar Lembaga Pengembangan dan Penjaminan Mutu Pendidikan: Universitas Negeri Yogyakarta.

Ndun, L. N. (2015). Teacher Question in the Junior High School English Classroom. A Thesis of the Graduate Program in English Language Studies. Sanata Dharma University Yogyakarta.

Padmadewi, N. N., Artini, L. P., \& Agustini, D. A. (2017). Pengantar Micro Teaching. Depok: Rajawali Press.

Rahardjo, M. (2017). Studi Kasus Dalam Penelitian Kualitatif: Konsep Dan Prosedurnya, 1-28. Retrieved from http://repository.uin-malang.ac.id/1104/1/Studi-kasus-dalam-penelitiankualitatif.pdf

Shomoossi, N. (2004). The effects of Teachers' Questioning Behaviour on EFL Classroom Interaction: A Classroom Reseacrh Study. The Reading Matrix, 4(2), 96-104.Retrieved from http://www.readingmatrix.com/articles/shomoossi/article.pdf

Sujariati, Rahman, Q., \& Mahmud, M. (2016). English Teacher's Questioning Strategies in EFL Classroom at SMAN 1 Bontomarannu. ELT Worldwide, 3(1), 107-121.Retrieved from http://ojs.unm.ac.id/ELT/article/download/1884/871

Tuan, L. T., \& Nhu, N. T. K. (2010). Theoretical Review on Oral Interaction in EFL Classrooms. Studies in Literature and Language, 1(4), 29-48. https://doi.org/10.3968/1415

Yang, C. C. (2010). Teacher Questions in Second Language Classrooms: An Investigation of Three Case Studies. Asian EFL Journal, 12(1), 181-201.Retrieved December 11, 2017, from http://asian-efl-journal.com/PDF/March-2010.pdf

Yuliawati, Mahmud, M., \& Mahmud, A. (2016). Teacher's questioning and students' critical thinking in EFL classroom interaction. ELT Worldwide, 3(2), 231-247.Retrieved December 10, 2017, from http://ojs.unm.ac.id/ELT/article/download/2261/1154 